SECTION 21. Pedagogy. Psychology. Innovations in the field of education.

Martynyuk Anastasiya Gannadiyevna student of 3 course, socially-humanitarian faculty, speciality practical psychology, Melitopol State pedagogical University named after Bohdan Khmelnytsky, Melitopol, Ukraine

\title{
METHODS OF GESTALT THERAPY \\ IN THE DEVELOPMENT OF PROFESSIONALLY IMPORTANT QUALITIES OF A FUTURE SPECIALIST
}

The article examines the effectiveness of the Gestalt approach in the development of professionally important qualities of the person of the future specialist.

Keywords: personality, professionalism, education.

\section{МЕТОДЫ ГЕШТАЛЬТ-ТЕРАПИИ В РАЗВИТИИ ПРОФЕССИОНАЛЬНО ВАЖНЫХ КАЧЕСТВ ЛИЧНОСТИ БУДУЩЕГО СПЕЦИАЛИСТ}

В статье рассматриваются вопросы эффективности гештальт подхода в развитии профессионально важных качеств личности будущего специалиста.

Ключевые слова: личность, профессионализм, образование.

Постановка проблемы. Сегодня гештальт-терапия стала одним из самых мощных направлений в современной психотерапии не только за рубежом, но и в России, Белоруссии, на Украине. Повышение эффективности образовательного процесса в вузах связано с формированием готовности выпускников к самостоятельному творческому поиску, умению в полной мере проявить таланты и способности, реализовать свой потенциал. Данная проблема актуальна для профессиональной подготовки будущих специалистов всех отраслей. Особый интерес представляет создание условий для развития личности в процессе общего и профессионального образования. Вместе с тем остаются недостаточно исследованными вопросы, касающиеся конкретизации, систематизации и целенаправленного формирования профессиональных качеств у студентов.

Профессиональная подготовка специалиста на сегодняшний день все больше связывается не только с овладением им системой знаний и умений по учебным предметам, но и с целенаправленным развитием 
профессионально-значимых качеств его личности, позволяющих будущему специалисту добиться успехов в своей профессиональной деятельности. При этом в числе имеющихся особенностей личности студентов могут быть и такие, которые значительно снижают эффективность овладения будущей профессией и требуют целенаправленной коррекционно-развивающей работы. В осуществлении коррекционной работы с устранения неблагоприятных особенностей личности студента, которые негативно влияют на развитие профессиональных качеств будущего специалиста, является применение гештальт подхода.

Изученность в литературе. В последние десятилетия проблемой развития профессиональних качеств занимаются В.А. Бодров, А.А. Деркач, В.Г. Зазыкин, М.М. Кашапов, А.В. Карпов, Е.А. Климов, Н.В. Кузьмина, В.ЈI. Марищук, А.К. Маркова, Н.П Фетискин, В.Д. Шадриков и др. Формирование и развитие профессионально важных качеств у студентов различных специальностей на этапе вузовского обучения представлено в работах А.Н. Богачева, Е.И. Кустовой, Н.Г. Мещериной, Н.В. Мухаметзяновой, О.А. Фроликовой, И.Ш. Шавалиевой и др. Однако при этом вне поля зрения ученых остаются вопросы, связанные с психологическим сопровождением данного процесса. На всех этапах своего профессионального становления человек действует под влиянием двух групп факторов: субъективных и объективных.

Субъективные факторы -это имеющиеся у конкретного человека задатки и способности, индивидуально-психологические свойства и особенности, его мотивация и уровень притязаний, самооценка, психологическая защита от ошибок и неудач [3].

Объективные факторы - это требования, нормы и ограничения, выдвигаемые со стороны профессии к его труду и наличию у него определенных свойств и особенностей: профессиональных знаний, умений и навыков, профессионально важных качеств. Успехи в деятельности обуславливаются соответствием этих двух групп факторов. В качестве субъективных факторов, обуславливающих успех в деятельности, выступают, как известно, «профессионально важные качества», которые трактуются в научной литературе неоднозначно. Так, В.Д.Шадриков понимает профессионально важные качества как индивидуальные качетва субъекта профессиональной деятельности, влияющие на продуктивность эффективность этой деятельности и успешность ее освоения.

Основная идея работы. Теоретико-методологический анализ литературы, об эффективности гештальт подхода в развитии профессионально важных качеств личности будущего специалиста.

Материалы теоетического анализа. В профессиональном образовании существует множество подходов, форм и методов обучения, которые различаются основными целями, отношением к учащимся, 
способами постановки целей, содержанием обучения, педагогическим управлением, а также психологическими теориями и концепциями, лежащими в основе каждого подхода. В данной работе рассматривается применение гештальт-метода в образовании, а именно использование этого метода в обученияи, и развитие у студентов профессионально значимых качеств. «Гештальт» - немецкое слово, означающее образ, фигуру, форму, целое или конфигурацию. В психологии под гештальтом понимают специфическую организацию частей, которая составляет определѐнное целое [1]. Уникальность гештальт-метода в том, что он не предлагает готовых рецептов, а даѐт знание общих закономерностей взаимодействия живых систем и окружающей их среды и умение выстраивать свою реальность на основе трѐх китов: актуальности, ответственности и осознанности.

В настоящее время результаты обучения и воспитания не всегда соответствуют социальным ожиданиям в отношении молодых специалистов. Это объясняется тем, что мы живем в «мире хаотических изменений», как называет его Питер Б. Вейл или «мире непредсказуемой среды», как пишет Э. Невис, в связи с этим некоторые методы обучения устарели и не эффективны на данном этапе. Поэтому есть потребность в выработке новых, более адекватных методов обучения [2] .

Вывод. Проведенное исследование показало что гештальт-терапия - одно из основных направлений гуманистической психологии, оригинальный метод групповой и индивидуальной психотерапии и личностного роста. Ориентируясь в большей степени на то, что происходит «здесь и сейчас», гештальт-терапия позволяет человеку лучше сознавать свои потребности, делать выбор и принимать ответственность за их удовлетворение или неудовлетворение. Это рождает чувство уверенности в себе, фасилитируя эго-функцию человека, формируя и стабилизируя его и «Я-концепцию». Основным принципом этого направления является принцип реальности, актуальности как во внутриличностном, так и в межличностном аспектах человеческого существования. Гештальт-терапия актуальна для психологического сопровождения подготовки специалистов на всех этапах обучения. Одним из факторов, препятствующих успешной профессиональной и личностной самореализации студентов, является накопившееся напряжение, связанное с прошлым негативным опытом, с непроявленными чувствами и эмоциями, которое заставляет реагировать в различных ситуациях однотипно, не творчески, с направленностью на избегание, а не на самореализацию.

И в заключении необходимо обратить внимание, что именно использование гештальт-метода в обучении студентов позволит выработать профессионально важные компетенции, так как гештальт - это не просто психотерапевтический метод, это метод, позволяющий сделать 
жизнь более наполненной ощущениями и более осмысленной. Он учит людей не только думать о жизни, но и переживать еѐ во всех еè проявлениях, открывать в себе всѐ новые и новые ресурсы, видеть и чувствовать новые грани окружающего мира и своей личности. Именно это повышает компетентность и профессионализм будущих психологов.

\section{Литература.}

1. Лебедева, А А Тендерные аспекты профессии психолога / А А Лебедева // Мужское и женское в культуре, МН-ПК, - СПб, 2005 -С 156-158

2. Малкина-Пых И.Г. Психосоматика: Справочник практического психолога.- М.: 2004.

3. Соловьева С.Л. Психотерапия: справочник практического психолога.M.: 2007. 